\title{
Impacts of Modern Glacier Changes on Surface Water Resources in Western and Northern Mongolia
}

\author{
Alexander Orkhonselenge ${ }^{1 *}$, Jonathan M. Harbor ${ }^{2,3}$ \\ ${ }^{1}$ Laboratory of Geochemistry \& Geomorphology, National University of Mongolia, Ulaanbaatar, Mongolia \\ ${ }^{2}$ Department of Earth, Atmospheric, \& Planetary Sciences, Purdue University, Lafayette, Indiana, USA \\ ${ }^{3}$ Department of Physical Geography \& Quaternary Geology, Stockholm University, Stockholm, Sweden \\ Email: *rkhnslng@num.edu.mn
}

How to cite this paper: Orkhonselenge, A. and Harbor, J.M. (2018) Impacts of Modern Glacier Changes on Surface Water Resources in Western and Northern Mongolia. Journal of Water Resource and Protection, 10, 559-576.

https://doi.org/10.4236/jwarp.2018.106031

Received: May 10, 2018

Accepted: June 24, 2018

Published: June 27, 2018

Copyright $\odot 2018$ by authors and Scientific Research Publishing Inc. This work is licensed under the Creative Commons Attribution International License (CC BY 4.0).

http://creativecommons.org/licenses/by/4.0/ Open Access

\begin{abstract}
Water trapped in glaciers and in lakes impounded by landforms created by glaciers (glacial lakes) are an important component of the hydrology and water resources in high mountain areas of Central Asia. Changes in modern glaciers and glacial lakes are an important component of the hydrology of watersheds in the Mongolian Altai and Khuvsgul Mountain Ranges, western and northern Mongolia, respectively. Here we focus on Mt. Ikh Turgen and Mt. Munkh Saridag, isolated mountains of the Mongolian Altai and Khuvsgul Mountain Ranges, respectively. We use remote sensing to track changes in modern glaciers over time with mapping at scales of 1:200,000 for Mt. Ikh Turgen and 1:90,000 for Mt. Munkh Saridag based on imagery from Google Earth, $30 \mathrm{~m}$ resolution Aster Digital Elevation Model (DEM) and $30 \mathrm{~m}$ resolution Landsat 5 TM. Mt. Ikh Turgen lost $45.6 \%$ of its total glacier area between $1970\left(41.4 \mathrm{~km}^{2}\right)$ and $2011\left(18.9 \mathrm{~km}^{2}\right)$ and the Equilibrium Line Altitude (ELA) of the glaciers increased in elevation by $98 \mathrm{~m}$ and $144 \mathrm{~m}$ on north and south aspects, respectively. Mt. Munkh Saridag lost $57.3 \%$ of its total glacier area between $1970\left(901 \mathrm{~m}^{2}\right)$ and $2007\left(381 \mathrm{~m}^{2}\right)$ and the local ELA rose by $47 \mathrm{~m}$ and $80 \mathrm{~m}$ on north and south aspects, respectively. These mountains are located at similar latitudes, and so the greater percentage loss of glacier area in Mt. Munkh Saridag and faster changes in ELAs in Mt. Ikh Turgen may reflect variations in elevation and aspect, duration of solar radiation, and vulnerability to solar radiation, as well as variations in glacier scale. This study demonstrates the importance of spatial analyses of modern glaciers in understanding the context of hydrological changes within which any sustainable water resource management plan must be situated.
\end{abstract}




\section{Keywords}

Surface Water, Overflow Dynamics, Modern Glaciers, Altai Mountains, Khuvsgul Mountains, Mongolia

\section{Introduction}

In Mongolia there were two major glaciations in the early and late Pleistocene [1], covering the Altai, Khangai, Khentii and Khuvsgul Mountain Ranges (Figure 1). There is evidence for three to four Pleistocene glaciations in the Altai overall, two to three Pleistocene glaciations in the Khangai and Khuvsgul, and one Pleistocene glaciation in the Khentii [2]. Today, glaciers occur in only a few mountains of the Altai, Khangai and Khuvsgul Mountain Ranges. The dominant style of glaciation recorded in the landforms and deposits of Mongolia is valley glaciation [1] including hanging glaciers along the mountain slopes and crests of highly-elevation mountains [3] [4]. Modern glaciers in the high mountain ranges in Mongolia play a vital role in water resources in Central Asia, and also in regional ecological, social and economic development. Modern glaciers in the high mountain ranges provide over $70 \%$ of fresh water resources in Mongolia [5] and small mountain glaciers in high latitudes and high altitudes are very sensitive to climate change [6]. Thus climate change can modulate water resources through altering glacier mass balances [7], and this has a large impact on regional development. There has been a lack of work linking glacier and surface water fluctuations, and the purpose of this paper is to provide such a connection for Mt. Ikh Turgen and Mt. Munkh Saridag in Mongolian Altai and Khuvsgul Mountain Ranges in western and northern Mongolia.

The Altai Mountain Range in Central Asia lies on the border between Mongolia, China, Kazakhstan and Russia (Figure 1). The Russian Altai has been the focus of much of the research to date on Altai paleoglaciation (e.g. [8]-[14]), with additional work focused on the extents of Pleistocene and modern glaciers (including during the Little Ice Age) in the Mongolian Altai [15]-[21]. Several reviews summarize our knowledge of the extent of Pleistocene glaciations (e.g. [9] [13] [14] [22] [23] [24]), and previous work has suggested that the limited extent of past glacier expansion in the Mongolian Altai reflects decreasing precipitation and increasing ELAs from the northwest to the southeast of the Altai [13] [25] [26]. Although long-term fluctuations of glaciers over the Pleistocene in the Altai Mountain Range have been investigated in previous studies [13] [15] [16] [19] [27], Holocene and modern glacier fluctuations in Mongolia have rarely been described [20] [22].

In the Khuvsgul Mountain Range, Tsegmid [1] estimated the extents of past glaciations based on glacial deposits, and absolute age dating suggests that maximum glacier advances were approximately synchronous across northern Mongolia [27]. Late Pleistocene glaciers around the Darkhad basin (Figure 2(B)) 


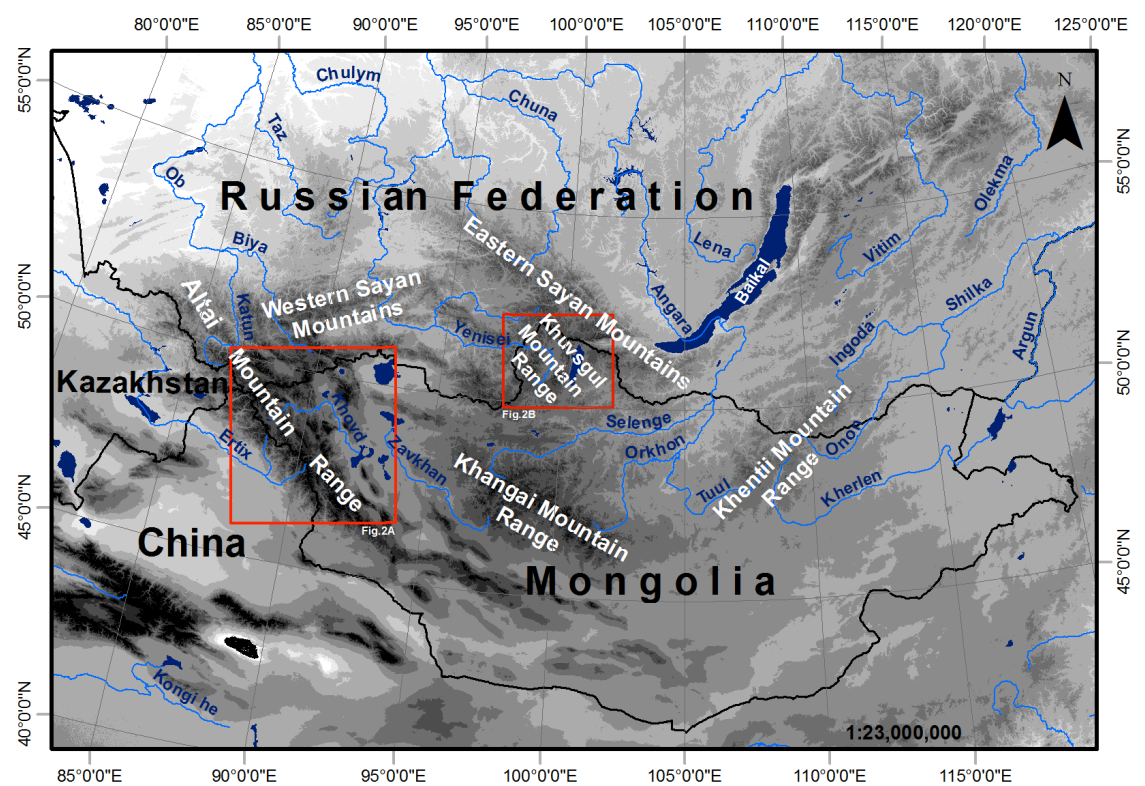

Figure 1. Location of the study areas in the Mongolian Altai and Khuvsgul Mountain Ranges. Red boxes with numbers denote locations in Figure 2.

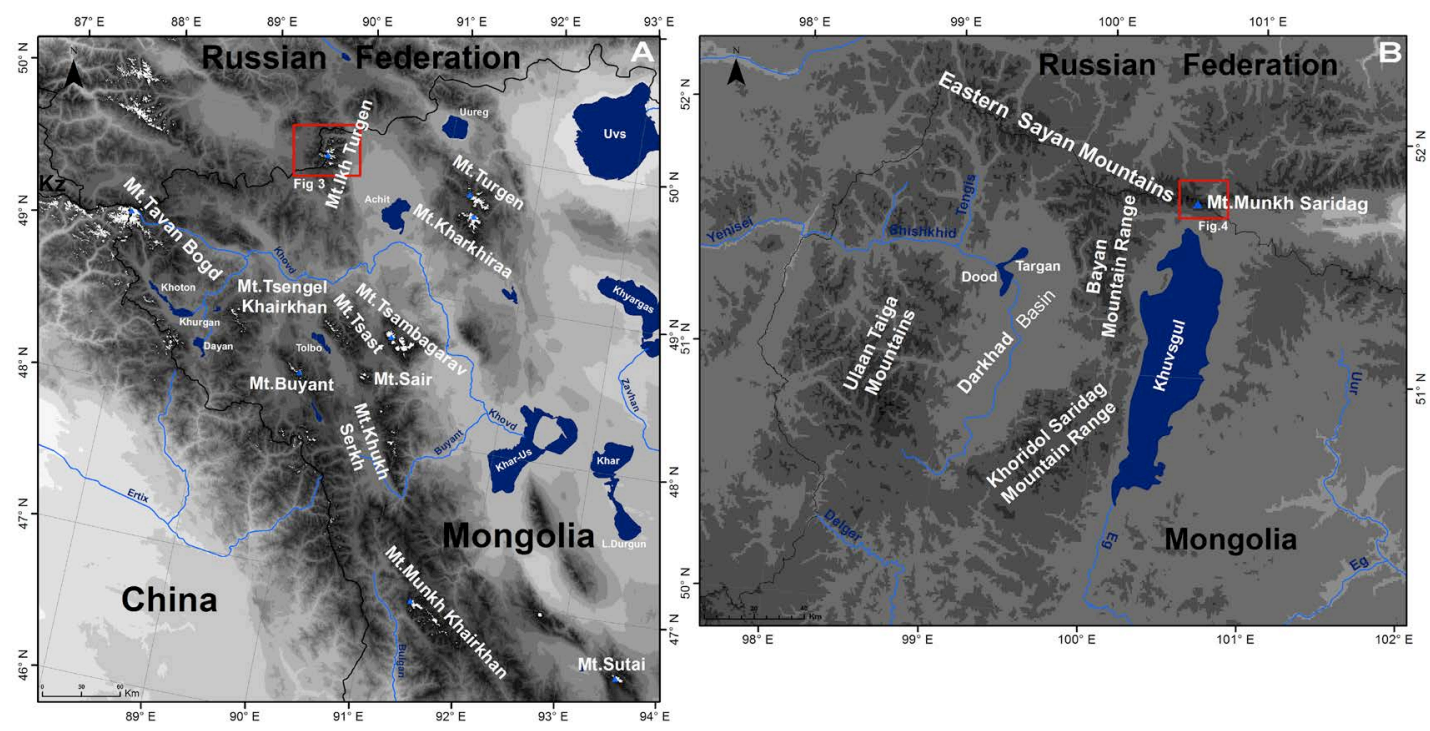

Figure 2. Topography of the Mongolian Altai (A) and Khuvsgul (B) Mountain Ranges including study areas (red boxes), Mt. Ikh Turgen (A)and Mt. Munkh Saridag (B) in Figure 3 \& Figure 4. These maps include locations of previous studies of paleoglaciology and glacial geomorphology.

advanced twice at 17 - $19 \mathrm{ka}$ and 35 - $53 \mathrm{ka}$, when end moraines and ELAs were at $\sim 1600 \mathrm{~m}$ a.s.l and 2100 - $2400 \mathrm{~m}$ a.s.l, respectively [27] in the surrounding Khuvsgul mountains (Figure 2(B)). The remnant end moraines and lateral moraines on the upper slopes and in the valleys of Rivers Tengis and Shishkhid, and intermontane basins (e.g. [28] [29]) indicate that large glaciers advanced in the Sayan and Khuvsgul Mountain Ranges in the late Pleistocene. During the latest extensive glaciations in the Late Pleistocene, Mt. Munkh Saridag was covered by ice from the Zhokhoiskiy and Okinskiy glaciers in the north, with an ice surface 
at $2100-2200 \mathrm{~m}$ a.s.l and an ice thickness of $300-400 \mathrm{~m}$ [6]. There was no glaciation during the Atlantic period (7000 - 7300 years ago) and modern glaciers have been present for the last 4000 - 5000 years [6].

Today, modern glaciers and their landforms in the Mongolian Altai and Khuvsgul Mountain Ranges include ice caps, valley glaciers, hanging glaciers, cirques, hummocky terrain, moraines and moraine-dammed lakes. Modern glaciers remain only in the highest mountains of the Altai, and several studies have focused on estimating the total current glaciated area. Contemporary glacier coverage in the Mongolian Altai has been estimated using different methods and datasets as $328 \mathrm{~km}^{2}$ [30], $>300 \mathrm{~km}^{2}$ [15] [17], about $540 \mathrm{~km}^{2}$ [31], $659 \mathrm{~km}^{2}$ [32] [33], around $850 \mathrm{~km}^{2}$ [18], $514 \mathrm{~km}^{2}$ [34], $423 \mathrm{~km}^{2}$ [35] and $376.4 \mathrm{~km}^{2}$ [22]. Additional studies of contemporary glaciation in the Mongolian Altai have provided detailed information for individual mountains and isolated massifs (e.g. [20] [22] [36]). Glacier areas for Mt. Tsambagarav in the Mongolian Altai have been estimated at $74.8 \mathrm{~km}^{2}$ [36] and $73.17 \mathrm{~km}^{2}$ [37]. Lehmkuhl [22] calculated the extent of modern glaciers in the northeastern part of the Mongolian Altai to be $33.8 \mathrm{~km}^{2}$ for Mt. Turgen and $39.5 \mathrm{~km}^{2}$ for Mt. Kharkhiraa. Total glacier coverages for Mt. Ikh Turgen, Mt. Munkh Khairkhan and Mt. Sutai in the Mongolian Altai (Figure 2(A)) have been estimated to be $31.8 \mathrm{~km}^{2}$ [20], $26.58 \mathrm{~km}^{2}$ and $12.57 \mathrm{~km}^{2}$ [37], respectively. Recent studies show that modern glaciers occupy small areas in the mountain ranges of Mongolia, and that glaciated areas have been decreasing rapidly. Valley glaciers are sensitive indicators of regional and local climates [38], and over a glacial cycle they respond to variations in the position and strength of major climate systems [21]. Current global climatic shifts are having a pronounced effect on glaciers in Mongolia [20], however the extent of both paleo and modern glacier changes is still unclear. In terms of more recent glacier changes, Lehmkuhl [22] identified large-scale glacier retreat from Holocene and Little Ice Age limits to positions in 1948 and 1991 in the northeastern part of the Mongolian Altai, and Davaa [5] estimated a shrinkage of $22 \%$ in the size of glaciers in the Mongolian Altai Mountain Range as a whole during the last 50 - 60 years. This is a major concern in a region that depends so heavily on glacial meltwater to sustain water supplies for agriculture and other ecosystem services in summer months. The mean depth of Mongolian glaciers is $55.8 \mathrm{~m}$ and the total water resource accumulatedin the glaciers has been estimated at about $62.6 \mathrm{~km}^{3}$ [32] [33]. Over the last 40 years, the area under glaciers had decreased by $6 \%$ [33]. Although concerns about glacier loss and sustainable water supplies were among the reasons that monitoring stations for glacial studies in Mongolia were established on Mt. Tsambagarav in 2007, on Mt. Tavan Bogd in 2012 and on Mt. Turgen in 2013 [39], further work on the linkage between glaciology and hydrology in Mongolia is needed. Here, we consider the linkage between glacial and hydrological variations based on dynamic changes of modern glaciers in the Mongolian Altai and Khuvsgul Mountain Ranges in western and northern Mongolia, respectively (Figure 1), compared to climate and hydrological changes in these areas. 


\section{Study Area}

\subsection{Mongolian Altai Mountain Range}

The Mongolian Altai Mountain Range (extending over 160,000 $\mathrm{km}^{2}$ ) is the most southeastern part of the Altai Mountain Range (over 248,900 km²) straddling the borders between Mongolia, China, Kazakhstan and Russia (Figure 1). The Mongolian Altai extends over $1000 \mathrm{~km}$ from Mt. Tavan Bogd (4374 m a.s.l) in the northwest to the Gichgene Mountain Range in the southeast [40]. In the Mongolian Altai, there are numerous branches and isolated mountains over $4000 \mathrm{~m}$ a.s.l. including Mt. Munkh Khairkhan (4231 m a.s.l.), Mt. Sutai (4226 m a.s.l.), Mt. Tsast Bogd (4208 m a.s.l.), Mt. Bugat (4041 m a.s.l.), Mt. Kharkhiraa (4040 m a.s.l), Mt. Ikh Turgen (4030 m a.s.l) and Mt. Turgen (4029 m a.s.l). Mt. Ikh Turgen, one of our study sites, is an isolated mountain in the southwest of Western Sayan Mountain Range on the border between Mongolia and Russia (Figure 1, Figure 2(A)).

Tectonically, the Mongolian Altai Mountain Range is an anticlinal ridge with intermontane valleys and depressions (Figure 2(A)) including the Depression of Great Lakes between the Mongolian Altai and Khangai Mountain Ranges, and the Valley of Lakes between the Govi Altai and Khangai Mountain Ranges. Geologically, the main mountains in the Mongolian Altai consist of dislocated Precambrian stratigraphic sequences and formations formed by mountain building movements during the late Tertiary and the early Quaternary [1]. The Mongolian and Govi Altai Mountain Ranges mainly consist of Archean and Proterozoic bedrocks. The Paleozoic deposits in the Altai-Sayan anticline belt were overlain by the Precambrian metamorphic rocks during the Caledonian mountain building movement [1].

Morphogenetic features in the Mongolian Altai include the tectonic-denudational landforms, erosion-depositional landforms, and depositional landforms. Modern glaciers occupy areas of $85 \mathrm{~km}^{2}$ in the Potanin glaciers, 10 $\mathrm{km}^{2}$ at the head of River Sagsai, more than $20 \mathrm{~km}^{2}$ in Mt. Tsast Bogd, $66 \mathrm{~km}^{2}$ in Mt. Munkh Khairkhan, $21 \mathrm{~km}^{2}$ in Mt. Deluun, $25 \mathrm{~km}^{2}$ in Mt. Tsast, more than $60 \mathrm{~km}^{2}$ in Mt. Turgen, and $2 \mathrm{~km}^{2}$ in Mt. Tsengel Khairkhan (Figure 2(A)).

At the Ulgii and Khovd meteorological stations, annual average air temperature is $1.8^{\circ} \mathrm{C}$, and annual average precipitation is $56 \mathrm{~mm}$ in Ulgii and $210 \mathrm{~mm}$ in Khovd. The Mongolian Altai acts as a barrier for moisture travelling from the west and northwest in Russia to the east and southeast in Mongolia. Equilibrium Line Altitudes (ELAs) are at $3000 \mathrm{~m}$ a.s.l. and $3700 \mathrm{~m}$ a.s.l. in the northwestern and southeastern mountains of the Mongolian Altai, respectively [13]. Meltwater from glaciers in the Mongolian Altai feeds rivers, including the River Khovd, which is a source for Lakes Khoton, Khurgan and Khar Us in the Mongolian Altai (Figure 2(A)).

\subsection{Khuvsgul Mountain Range}

The Khuvsgul Mountain Range, the southeastern tip of the Eastern Sayan 
Mountain Range, is located in northern Mongolia (Figure 1). The Khuvsgul is surrounded by the Khangai Mountain Range in the south, isolated mountains in the drainage basins of Rivers Selenge and Orkhon in the southeast, and the Sayan Mountain Range in the north. The western mountains of the Khuvsgul are steep and sharply dissected by cliffs, whereas the northeastern and eastern mountains are gentle and domed-shaped. Most mountains in the Khuvsgul Mountain Range extend from southwest to northeast. Only Mt. Munkh Saridag, the highest peak in the Khuvsgul currently contains modern glaciers [1]. Bedrock in the Khuvsgul is largely schist, with granites in the Sayan Mountain Range and Mt. Ulaan Taiga, and carbonates in the Khoridol Saridag Mountain Range. Generally, carbonate and volcanic rocks underlie the western and the eastern Khuvsgul Mountains, respectively.

The predominant climate type in the Khuvsgul is an Eastern Siberian type of ultra-continental climate with a significant difference between winter and summer temperatures, high aridity, and large amplitudes of absolute maxima and minima [6] prevail. The annual average precipitation in the Khuvsgul is 190-300 $\mathrm{mm}$ at lower elevations and $400-500 \mathrm{~mm}$ in the high mountains. Most of precipitation is in July, evaporation is low, summers are cool, and winters are extremely cold. The annual average temperature amplitude is high due to cool summers. The annual average temperature is $-1.9^{\circ} \mathrm{C}$ with an annual air temperature amplitude of $70^{\circ} \mathrm{C}-80^{\circ} \mathrm{C}$ and daily air temperature amplitude of $20^{\circ} \mathrm{C}$ $25^{\circ} \mathrm{C}$ at the Khatgal meteorological station. These severe climatic conditions are responsible for the widespread existence of permafrost and associated cryogenic landforms in the Khuvsgul Mountain Range.

The Mt. Munkh Saridag (3491 m a.s.l) study site is the highest isolated mountain in the Khuvsgul Mountain Range and is located in the northeastern end of the Khuvsgul at the border between Mongolia and Russia (Figure 1, Figure 2(B)).

\section{Methods}

In this study, we reconstruct changes in glacier extent and connect this to previous observations of changes in both climate and hydrology. Changes in modern glaciers are estimated by comparing glacier extent from Landsat imagesfor Mt. Ikh Turgen (08/19/1998, 08/07/2002, 08/23/2011) and for Mt. Munkh Saridag (07/23/1986, 08/06/2000, 07/18/2007), 1:100,000 topographical maps (1970) and Google Earth. For satellite images with a high percentage of cloud cover, additional detail was provided using Google Earth's 3D viewing capability. The extent of modern glaciers was mapped on the basis of ice limits identified visually from the remote sensing data and ASTER Global DEM data (AGDEM, 30 $\mathrm{m}$ resolution) (Figure 3, Figure 4). Snow indexes (NDSI) were calculated for Mt. Ikh Turgen and Mt. Munkh Saridag using a formula (NDSI = (GREEN SWIR1)/(GREEN + SWIR1)) [41], to enhance the contrast between ice and snow. To predict potential future changes in glaciers, we used best-fit extrapolation 


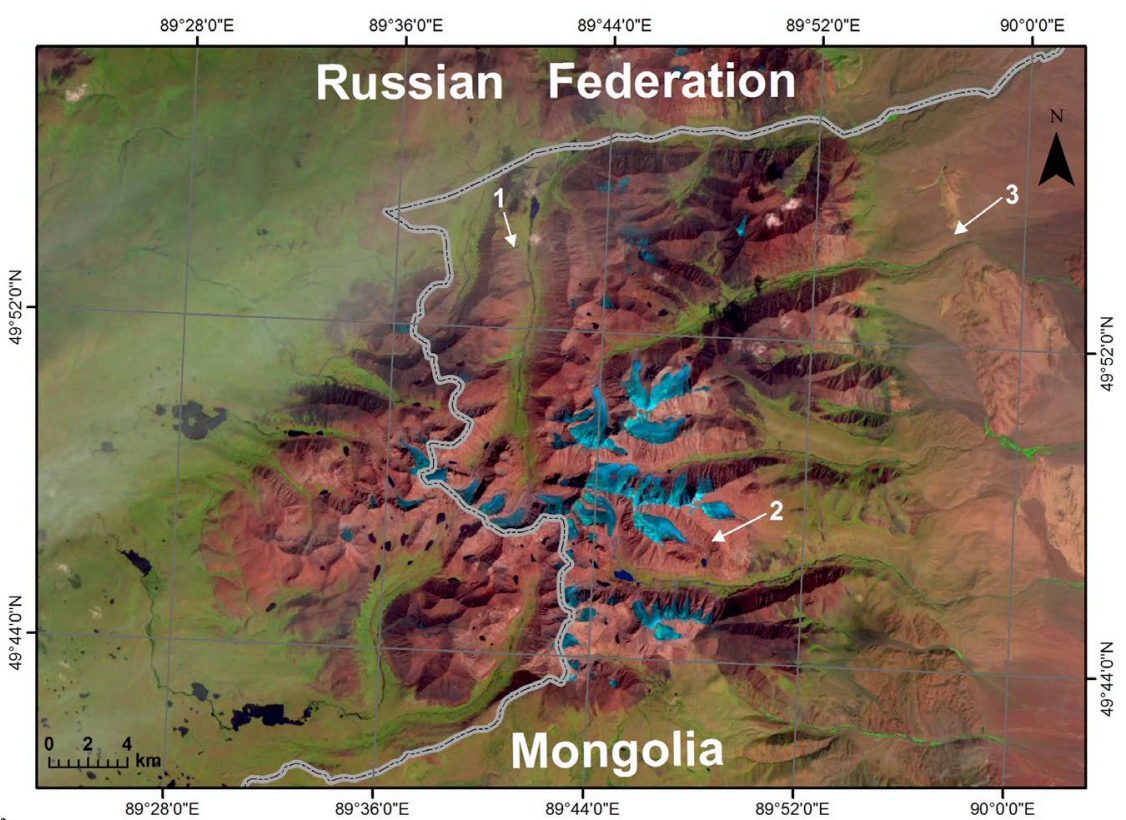

Figure 3. The extent and distribution of modern glaciers on Mt. Ikh Turgen (in blue) with background features of lowlands (in dark green) and mountains (in brown) on Landsat image, and features of past glaciation: 1) Glacial valley; 2) Glacial cirque and 3) Terminal moraine.

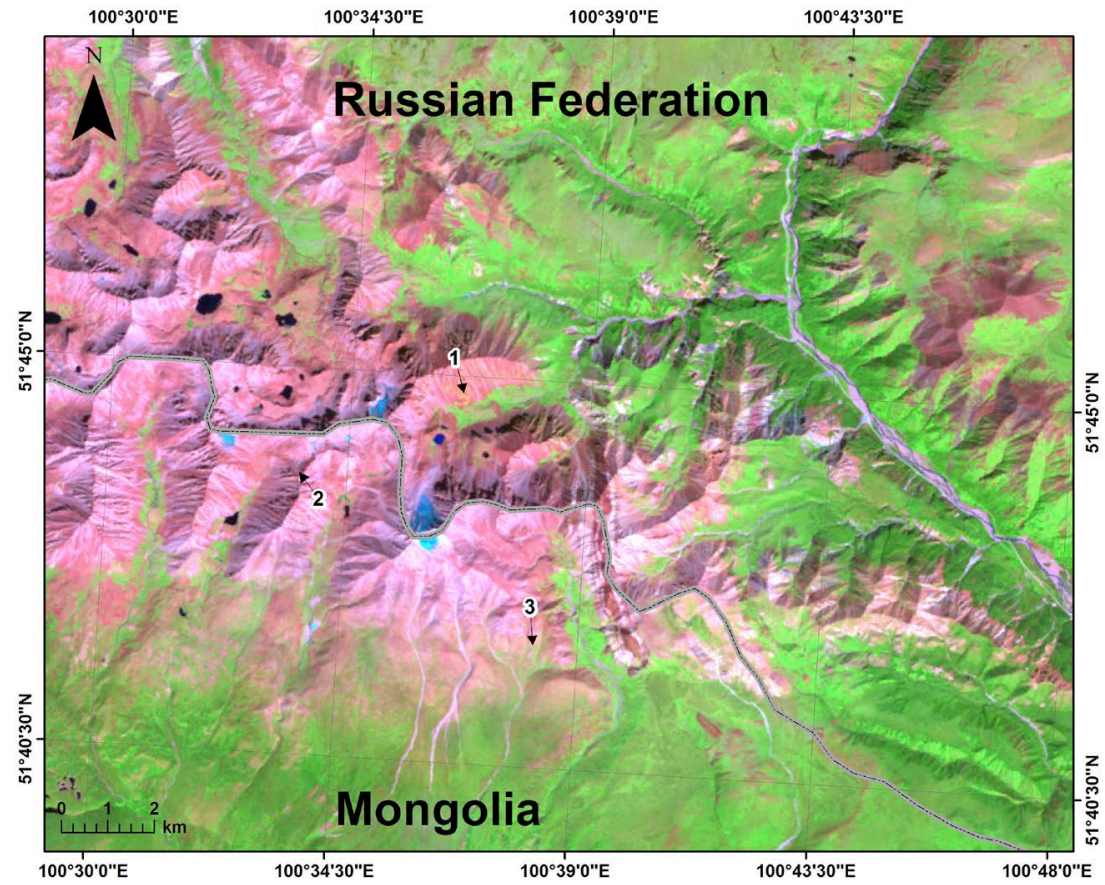

Figure 4. The extent and distribution of modern glaciers on Mt. Munkh Saridag (in blue) with background features of lowlands (in light green) and mountains (in pink) on Landsat image, and features of past glaciation: 1) Glacial valley; 2) Glacial cirque and 3) Terminal moraine.

of past changes to estimate the timescale over which glaciers are likely to disappear from each field area. Although simplistic, in the absence of more detailed 
data and models, this approach provides an estimate of the timescale of change that is helpful in conveying a sense of urgency about these changes to decision makers working on water resources management.

\section{Results and Discussion}

\subsection{Modern Glaciers}

Glacier mapping identifies ice caps, valley glaciers and hanging glaciers in the study areas (Figure 3, Figure 4). The area of modern glaciers on Mt. Ikh Turgen has decreased from $41.4 \mathrm{~km}^{2}$ in 1970 , to $24.6 \mathrm{~km}^{2}$ in $1998,21.69 \mathrm{~km}^{2}$ in 2002 and $18.9 \mathrm{~km}^{2}$ in 2011 (Figure 5). Thus glacier area has decreased by $45.6 \%$ between 1970 and 2011. The ELAs of the glaciers were at $2843 \mathrm{~m}$ and $3192 \mathrm{~m}$ a.s.l on the north and south aspects, respectively, in 1970, and increased to $2987 \mathrm{~m}$ and 3290 $\mathrm{m}$ a.s.l on the north and south aspects, respectively, by 2011, an increase in ELA elevation by $144 \mathrm{~m}$ and $98 \mathrm{~m}$, respectively. The melt rate of the glaciers is higher on southeast, south and southwest facing aspects than on slopes with a northern aspect. A simple linear extrapolation of the empirical data suggests that the current glaciers remaining on Mt. Ikh Turgen will have melted away completely in $\sim 27$ years (Figure 5) if current climate changes continue. This is a general estimation and is intended to convey the approximate timescale of major change, rather then the exact year when the last ice will disappear.

On Mt. Munkh Saridag, modern glaciers remain as ice caps on top of the mountain plus in a few large cirques located at about $3000 \mathrm{~m}$ a.s.l. (Figure 2(B), Figure 4). Recent moraines associated with modern glaciers are located at 2705 ma.s.l. and there is a mass wasting surface $270 \mathrm{~m}$ wide and $500 \mathrm{~m}$ long adjacent to a small lake.Areas of modern glaciers on Mt. Munkh Saridag were $901 \mathrm{~m}^{2}$ in $1970,850.1 \mathrm{~m}^{2}$ in $1986,545 \mathrm{~m}^{2}$ in 2000 and $381 \mathrm{~m}^{2}$ in 2007. Thus the glaciated area has decreased by $57.3 \%$ between 1970 and 2007. Extrapolating the empirical data suggests that the current glaciers remaining on Mt. Munkh Saridag will have melted away completely in just a few years (Figure 6). This is a general estimate and is intended to convey the approximate timescale of major change, rather than the exact year when the last ice will disappear. During the period between 1970 and 2007 when the glacier extent was reduced by $57.3 \%$, meteorological data indicate that there was a $2.16^{\circ} \mathrm{C}$ increase in average annual temperature at the Khankh meteorological stations located $22 \mathrm{~km}$ from Mt. Munkh Saridag at an elevation of $1650 \mathrm{~m}$ a.s.l. In 1970, ELAs were at $2892 \mathrm{~m}$ and $3150 \mathrm{~m}$ a.s.l. on north and south aspects, respectively, and by 2007, these had risen to $2939 \mathrm{~m}$ and $3230 \mathrm{~m}$ a.s.l., representing an ELA elevation increases of $47 \mathrm{~m}$ and $80 \mathrm{~m}$, respectively. The glaciers that occurred on southwest and west facing slopes in 1970 represented $4.1 \%$ of the ice area, and these had all disappeared completely by 2007 . In $2007,71.1 \%$ of total remaining glacier area was on north facing slopes. According to Kitov et al. [6], a comparison with earlier data shows that the lower boundary of glaciers on Mt. Munkh Saridag was $2935 \mathrm{~m}$ a.s.l. in 2006, 2897 m a.s.l. in 1962, and 2803 m a.s.l. in 1906. Shrinkage of glaciers since 


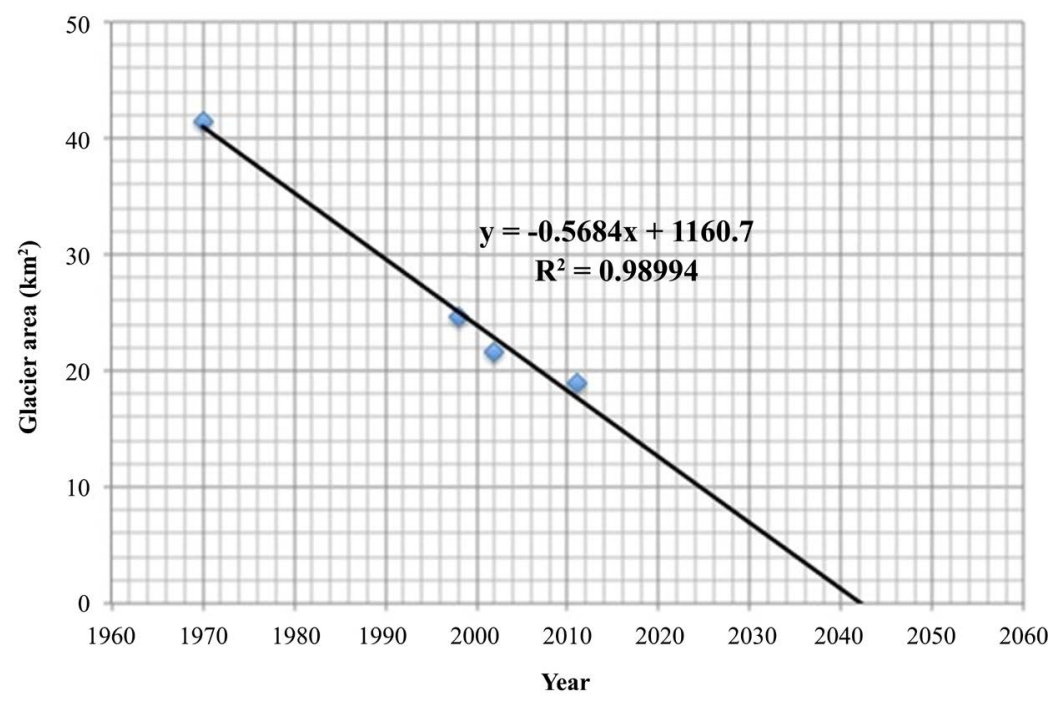

Figure 5. Recent glacier changes on Mt. Ikh Turgen (data on glacier area from this study). Linear extrapolation of this trend suggests that the glaciers will disappear by $\sim 2042$.

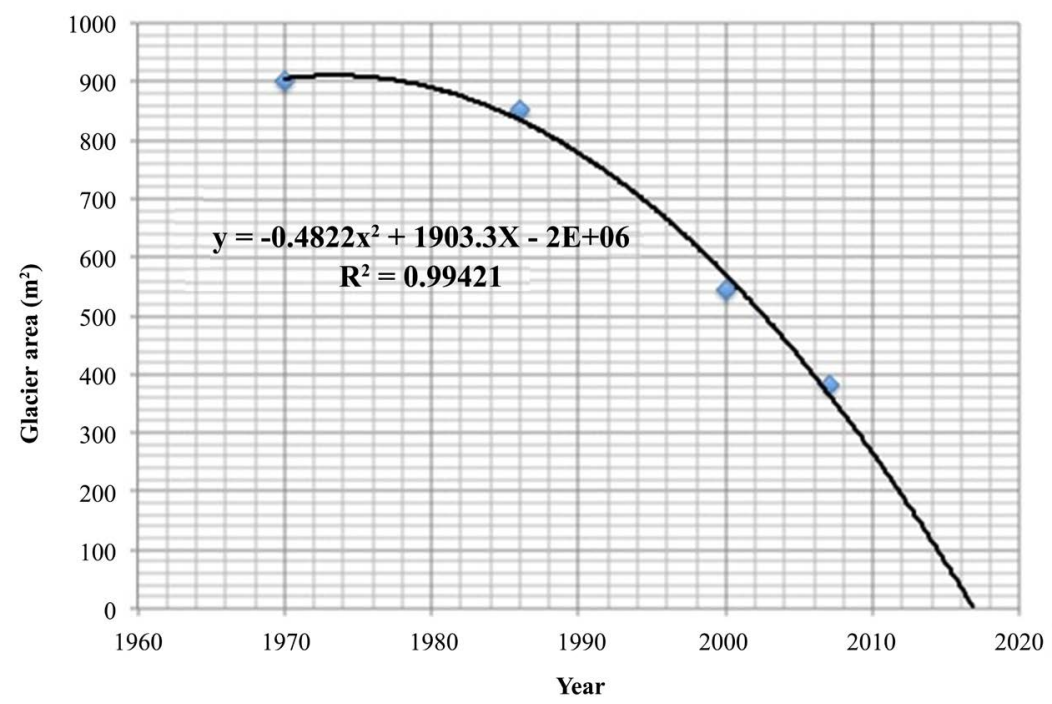

Figure 6. Recent glacier changes on Mt. Munkh Saridag (data on glacier area from this study). Non-linear extrapolation suggests that the glaciers will disappear by $\sim 2017$.

the end of the Little Ice Age has decreased glacier area by half (from 0.68 to 0.34 $\mathrm{km}^{2}$ ), over the past 160 years, glacier area on the Eastern Sayan Mountains decreased by $49 \%$, and the terminus of the largest glacier retreated by $570 \mathrm{~m}$ in length and $124 \mathrm{~m}$ in height [6]. The work presented here allows for a comparison of modern changes in glacier extent for two mountains located at similar latitudes.

Although Mt. Munkh Saridag is located slightly further north $\left(51^{\circ} 40^{\prime}\right.$ $51^{\circ} 50^{\prime} \mathrm{N}$ latitude) than Mt. Ikh Turgen $\left(49^{\circ} 40^{\prime}-50^{\circ} 00^{\prime} \mathrm{N}\right.$ latitude), changes in modern glacier area on Mt. Munkh Saridag (57.3\% reduction) are occurring slightly faster than on Mt. Ikh Turgen (45.6\% reduction). The ELAs of the mod- 
ern glaciers are rising faster on north and south aspects on Mt. Ikh Turgen than on Mt. Munkh Saridag. These differences may reflect the fact that the glacier extent on Mt. Munkh Saridag is much smaller than on Mt. Ikh Turgen. This difference in scale can also explain why the glacial lake area on Mt. Ikh Turgen has increased from $10.37 \mathrm{~km}^{2}$ in 1970 to $10.41 \mathrm{~km}^{2}$ in 2011 at the same time as the relatively large glaciers have been melting away, while glacial lake area on Mt. Munkh Saridag has decreased from $0.726 \mathrm{~km}^{2}$ in 1970 to $0.624 \mathrm{~km}^{2}$ in 2007 at the same time as the very small glaciers have shrunk in size. Extrapolating recent trends of glacier change suggest that Mt. Ikh Turgen and Mt. Munkh Saridag will be ice free in about 2042 and 2017, respectively (Figure 5, Figure 6).

Given the role that glaciers play in sustaining water flow during summer months, and the increase in annual flow that has come from recent glacier melt that has exceeded accumulation from snowfall, we predict that overall river flow, and in particular summer base flow in rivers fed by these glaciers, will decrease. Only if the loss of glacier melt is replaced by enhanced summer precipitation would river flow be maintained at current levels.

Overall, it is clear that modern glaciers in northern Mongolia vary significantly in size and have retreated at different rates depending on physical parameters such as topography, including elevation and aspect, vulnerability of the mountain glaciers to solar insolation, and duration of solar radiation for individual mountains. Previous studies [20] [22] have documented rapid retreat of modern glaciers in Mongolia during periods of glacier observation (such as a $\sim 29 \%$ reduction in glacier area in Mt. Tsambagarav between 1970 and 2000 [36]). Such changes are consistent with decreases in glacier areas in mountain ranges throughout the world that have been caused by global climate change [42] [43].

\subsection{Surface Water}

In this section we consider the linkage between glacial and hydrological fluctuations for Mt. Ikh Turgen and Mt. Munkh Saridag in western and northern Mongolia, respectively. Because Mongolia is very sensitive to climate change as a result of its geographic location and because of its socio-economic condition and reliance on pastoral animal husbandry, a nomadic way of life, and rain-fed agriculture, climate change that alters the Mongolian ecosystem and causes water shortages and desertification will result in severe economic impacts [44]. Hydrological changes driven by climate change and anthropogenic influences include enhanced glacier melt and permafrost thaw [5]. The maximum ice depth has decreased by $35 \mathrm{~cm}$ and the duration of ice cover has been shortened by 5 44 days [5]. The regime of spring floods has been advanced by 20 days in rivers draining the southern slopes of the Mongolian Altai and by 5 - 10 days in rivers draining the northern slopes of the Khuvsgul [5]. Average annual river flow in Mongolia (Figure 7) increased from the late 1970s to the early 1990s, and then decreased to 2010. However, during this later period of overall decrease, Davaa 


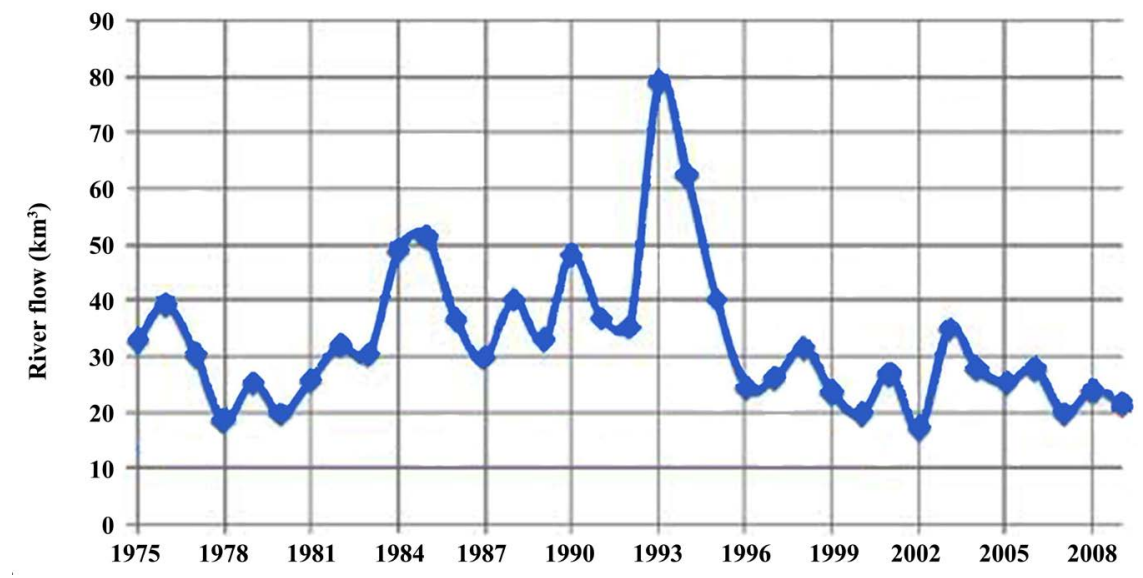

Figure 7. Dynamics of the total river flow in Mongolia modified from Davaa (2010).

[5] observed that rivers draining the glaciated catchments of the Mongolian Altai Mountain Range and continuous permafrost catchments of the Khuvsgul Mountains increased in annual and seasonal flows [5]. The annual average water discharge of rivers draining from the Altai and Khuvsgul Mountain Ranges has increased by $15 \%-35 \%$ in the last 30 - 70 years compared to long-term averages [5]. Similarly, lake area overall in Mongolia has decreased by $373 \mathrm{~km}^{2}$ in the last 60 years, with fluctuations including increases in area between 1960 and 1990 and further reductions since 1996, however lake areas have increased for large lakes located in the permafrost zone and lakes fed by glacier melt [5]. For example, since 1993 water levels in Lake Khuvsgul, located in the permafrost zone, have increased at the same time as water levels in Lakes Uvs and Khar Us, located in the arid zone have decreased [5]. Overall this suggests that during a period of overall reductions in surface water availability, ecosystems and human uses in catchments with permafrost and glaciers have been sustained by additional water from ice melt. However, the glacier component of this additional water will be lost as the glaciers disappear, likely leading to even more rapid hydrologic changes in the future than in other parts of Mongolia.

The average annual temperature in Mongolia has been increasing (Figure 8). Average annual temperature increased by $2.17^{\circ} \mathrm{C}$ overall, and by $1.9^{\circ} \mathrm{C}-2.28^{\circ} \mathrm{C}$ in the high mountains and $1.6^{\circ} \mathrm{C}-1.7^{\circ} \mathrm{C}$ in the Govi desert since 1940 [45]. Since 1940 , the average winter temperature has been increasing noticeably as compared to the summer temperature, and winter precipitation increased while warm season precipitation decreased slightly [46]. These temperature increases and precipitation changes are likely to have driven observed changes in glacier extent, river discharge, and lake area. For the future, climate modeling based on the greenhouse gas (GHG) A1B scenario estimates an increase in average temperature in the next 100 years of $2.6^{\circ} \mathrm{C}$ in winter and $2.4^{\circ} \mathrm{C}$ in summer [46]. This temperature rise, coupled with changes to short, heavy rain instead of long-lasting rain events, will increase the stress on traditional herding lifestyles, thus affecting the social-ecological conditions of Mongolia [47]. It is predicted 


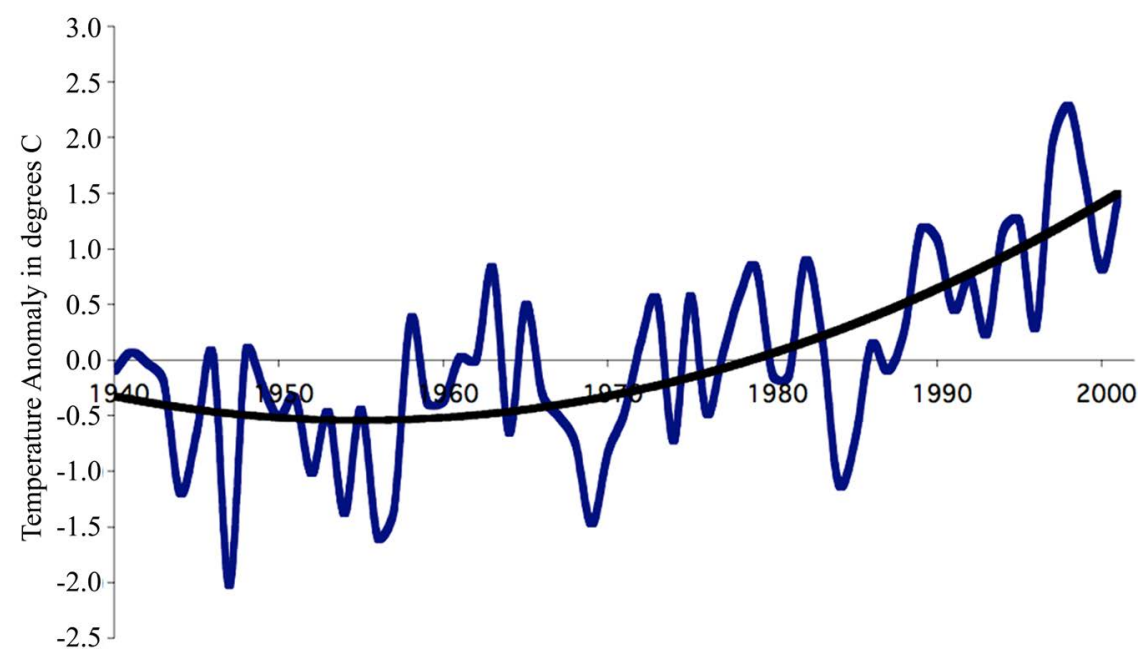

Figure 8. Temperature trend between 1940 and 2001 in Mongolia, modified from Batima et al. (2005).

that decreases in snowfall, increased tree cutting, the melting of permafrost, intensifying drying trends, destruction of riparian zone shrubs and swamps, and overgrazing all interact, in a non-linear way, resulting in the disappearance of water sources including small streams, lakes and springs in central Mongolia as a result of the warmer and dryer climate [48]. A decline in the number of places to access surface water disrupts the traditional nomadic pastoral pattern of seasonal grazing. Similar trends of climate and ecological change have been identified in the Depression of Great Lakes region between Altai and Khangai Mountain Ranges. In this semi-arid region, surface water is a critical resource for both humans and animals.

In the early $21^{\text {st }}$ century, when climate in Mongolia will continue to change dramatically [49], global climate change, population growth, river damming, large-scale water abstractions, and rising levels of pollution exert multiple pressures on regional water resources [50]. Climate change response measures will help to address the inevitable need to adapt to meet the requirements of sustainable development strategies in Mongolia [49].

\subsection{Water Management}

The ongoing rapid retreat and loss of glaciers in high mountains in Mongolia due to climate warming lead to challenges in the management of rivers and water resources. It is difficult to monitor the vast hydro-network in Mongolia, and to identify small lakes and disappearing glaciers, due to the fact that Mongolia occupies a large territory and has a low population density [5]. Thus hydrologic modeling based on climate change scenarios is an important basis for water management strategies. This type of modeling suggests that water stresses will increase under likely climate change scenarios [5].

Mongolia has scarce water resources and will face major challenges to adapt to climate change, particularly in areas where enhanced water from glacier melt 
will be lost when the glaciers disappear. Global warming, and regional and local changes in water resources related to glacier melting and permafrost thawing will have a significant impact on environmental conditions, ecology, socio-economic outcomes, and human life. Management decisions that impact catchments are often made on the scale of political regions, rather than hydrologic regions (catchments) [50]. However management of a glacier-based catchment with numerous rivers and lakes basins that is likely to undergo major glacier melting-induced dynamical changes would be better approached in an integrated catchment-scale manner aimed at minimizing ecological and socio-economic impacts. For example, the catchments of the Altai and Khuvsgul Mountain Ranges should ideally be treated as transboundary regions covering four and two nations, respectively, with international coordination in management through Integrated River Basin Management (IRBM) that includes development of reservoirs to store glacier melting water for hydropower generation, drinking water, industrial and pasture water supply [5]. Protection of runoff formation zones is also needed, even if these are in different political regions than downstream areas, as is efficient and economic use of water resources and improved environmental monitoring (extension and modernization of the observation network), modeling, remote sensing, data integration and regional cooperation.

Mongolia has limited human, technical and financial capacities to solve the multi-faceted threat caused by climate change [49], and because the impacts of climate change on the ecological system and natural resources in Mongolia will dramatically affect almost all sectors of the national economy, climate change response measures should address the need to adapt to climate change in ways that also archive the sustainable development strategies of Mongolia [46]. Numerous policies, plans and decisions for integrated environmental management have been made at national and international levels since joining the UN Framework Convention on Climate Change (UNFCCC) and the Kyoto Protocol in the 1990s. For example, the Parliament of Mongolia has passed several laws directed toward environmental protection, including the State Policy on Environment (1997), which forms the legal basis for the protection of Mongolia's natural resources, and at the international level Mongolia has joined 14 environment-related UN Conventions and Treaties [49]. However, there is a gap between the plans and treaties and actual implementation on the ground, especially in remote areas.

In Central Asia, groundwater is shallow, rivers and lakes have unique water-dependent ecosystems, and human societies have developed in close integration with limited water resources [50]. It is in such situations that Integrated Water Resources Management (IWRM) has great potential to contribute to more secure livelihoods, increased environmental sustainability and greater social harmony. To archive this requires that water resources are managed efficiently, with minimization of unproductive water losses in water delivery and water demand [51] and proactive efforts to prepare for future changes in water 
availability. The Asia-Pacific Adaptation Network (APAN), a key regional initiative to build climate resilience of vulnerable human systems, ecosystems and economies through the mobilization of knowledge and technologies to support adaptation capacity building, policy-setting, planning, and best practices, can provide a road-map for good adaptation knowledge and practices in Mongolia. However, significant barriers persist for adaptation efforts in developing countries, including a lack of the necessary finance, knowledge, and technology for reducing vulnerability to climate change that is an important prerequisite for successful adaptation efforts [44]. Although IWRM requires a complete transdisciplinary assessment of the environmental and socio-economic conditions in local and regional contexts, studies such as that presented here contribute to the scientific base knowledge of changing precipitation-glacier-inflow-runoff-outflow-storage relationships that are necessary component of integrated decision making.

\section{Conclusions}

In the Mongolian Altai and the Khuvsgul Mountain Ranges in western and northern Mongolia, modern glaciers exist as small ice caps centered on the mountain peaks (Figure 3, Figure 4). The changing extent of these glaciers has significant impacts on water resources that must be considered in future water management.

Changes in modern glaciers have been dramatic since the 1970s. Glacier areas on Mt. Ikh Turgen in the Mongolian Altai and Mt. Munkh Saridag in the Khuvsgul Mountain Ranges have decreased by $45.6 \%$ between 1970 and 2011 and 57.3\% between 1970 and 2007, respectively. Over the same period, the ELAs of the modern glaciers on Mt. Ikh Turgen have increased by $98 \mathrm{~m}$ and $144 \mathrm{~m}$ on north and south aspects, respectively, and on Mt. Munkh Saridag by $47 \mathrm{~m}$ and $80 \mathrm{~m}$ on north and south aspects, respectively. Although these mountains are located at similar latitudes, there is a faster reduction of glacier areas on Mt. Munkh Saridag and faster changes in ELA elevation on Mt. Ikh Turgen. These differences may reflect glacier scale and may also be related to differences in elevations and aspect, durations of solar radiation and vulnerability to the solar insolation for each individual mountain. Extrapolations of past change suggest that glaciers will be gone from Mt. Munkh Saridag in a few years, and from Mt. Ikh Turgen in a few decades. This will remove glacier melt as an important component of summer water supply for natural and human uses.

More sophisticated glaciological and hydrological observations and modeling is urgently needed to support local and regional water management policy and implementation. Integrated water management is the most suitable approach for this region, which includes diverse landscapes and ecosystems in catchments that cut across national and internal administrative units. Building on key linkages between glaciology and hydrology, future work should involve extensive fieldwork and modeling studies to examine the climate drivers that underlie 
modern glacier changes, as the basis for refined predictions of glaciological and hydrological changes that will be key to sustainable management of water resources in the changing Mongolian environment.

\section{Acknowledgements}

We would like to thank the Ministry of Environment and Green Development of Mongolia in Ulaanbaatar and its branch in Ulgii for their support to our field survey, and Dr. Robin Blomdin of Stockholm University for advice on remote sensing and mapping.

\section{References}

[1] Tsegmid, Sh. (1969) Physical Geography of Mongolia. Institute of Geography \& Permafrost, Mongolian Academy of Sciences. State Press, Ulaanbaatar, 405 p. [In Mongolian]

[2] Jigj, S. (1976) A Brief Description of Paleoglaciations and Paleoglaciers. Ulaanbaatar, 51 p. [In Mongolian]

[3] Obruchev, V.A. (1931) Evidence of Glaciation Periods in North and Central Asia. Bulletin of Quaternary Research, 3, AN SSSR.

[4] Ivanov, A.H. (1949) Glaciations of Northeast Part of Mongolian Altai. Proceedings of Mongolian Commission, 38, Moscow-Leningrad.

[5] Davaa, G. (2010) Climate Change Impacts on Water Resources in Mongolia. Proceedings of Consultative Meeting on Integration of Climate Change Adaptation into Sustainable Development in Mongolia, Institute for Global Environmental Strategies (IGES), 30-36.

[6] Kitov, A.D., Kovalenko, S.N., Plyusnin, V.M. and Suvorov, E.G. (2015) Modern Changes of the High-Mountain Landscapes and Glaciation in Southern Siberia (Russia) by the Example of the Eastern Sayan Mountains. Environmental Earth Science, 74, 1931-1946. https://doi.org/10.1007/s12665-015-4455-y

[7] Liu, Y., Wu, J., Liu, Y., Hu, B.X., Hao, Y., Huo, X., Fan, Y., Yeh, T.J. and Wang, Z.L. (2015) Analyzing Effects of Climate Change on Streamflow in a Glacier Mountain Catchment Using an ARMA Model. Quarternary International, 358, 137-145. https://doi.org/10.1016/j.quaint.2014.10.001

[8] Baryshnikov, G.J. (1992) Die Entwicklung des Reliefs der Übergangszonen von Bergländernim Kanäozoikum. University of Tomsk Press, Tomsk, 181 p. [In German]

[9] Butvilovkuy, V.V. (1993) Paleogeography of Last Glaciation and Holocene of Altai: Event-Catastrophic Model. Tomsk University Press, Tomsk, 253. [In Russian]

[10] Grosswald, M.G., Kuhle, M. and Fastook, J.L. (1994) Würm Glaciation of Lake Issyk-Kul Area, Tian Shan Mts.: A Case Study in Glacial History of Central Asia. GeoJournal, 33, 273-310. https://doi.org/10.1007/BF00812878

[11] Grosswald, M.G. and Rudoy, A.N. (1996) Quaternary Glacier-Dammed Lakes in the Mountains of Siberia. Polar Geography, 20, 180-198. https://doi.org/10.1080/10889379609377599

[12] Rudoy, A.N. (2002) Glacier-Dammed Lakes and Geological Work of Glacial Superfloods in the Late Pleistocene, Southern Siberia, Altai Mountains. Quaternary International, 87, 119-140. https://doi.org/10.1016/S1040-6182(01)00066-0

[13] Lehmkuhl, F., Klinge, M. and Stauch, G. (2004) The Extent of Late Pleistocene 
Glaciations in the Altai and Khangai Mountains. In: Ehlers, J. and Gibbard, P.L., Eds., Quaternary Glaciations-Extent and Chronology. Part III, Elsevier B. V, Amsterdam, 243-454.

[14] Lehmkuhl, F. and Owen, L.A. (2005) Late Quaternary Glaciation of Tibet and the Bordering Mountains: A Review. Boreas, 34, 87-100. https://doi.org/10.1080/03009480510012908

[15] Devjatkin, E.V. (1981) Cenozoic of Inner Asia. Nauka, Moscow, 196 p. [In Russian]

[16] Florensov, N.N. and Korzhnev, S.S. (1982) Geomorphology of Mongolian People Republic. Joint Soviet-Mongolian Scientific Research Geologic Expeditions. Transactions, Vol. 28, Moscow. (In Russian)

[17] Lehmkuhl, F. (1998) Quaternary Glaciations in Central and Western Mongolia. Quaternary Processes, 6, 153-167.

[18] Klinge, M. (2001) Glazial geomorphologische Untersuchungenim Mongolischen Altai als Beitrag zurjung quartären Landschafts-und Klimageschichte der Westmongolei. Aachener Geographische Arbeiten, 35, 125. (In German)

[19] Lehmkuhl, F., Klinge, M. and Stauch, G. (2011) The Extent and Timing of Late Pleistocene Glaciations in the Altai and Neighboring Mountains Systems. In: Ehlers, J. and Gibbards, P.L., Eds., Development in Quaternary Science-Extent ad Chronology-A Closer Look, Vol. 15, Elsevier B. V., Amsterdam, 967-979.

[20] Kamp, U., McManigal, K.G., Dashtseren, A. and Walther, M. (2013) Documenting Glacial Changes between 1910, 1970, 1992 and 2010 in the Turgen Mountains, Mongolian Altai, Using Repeat Photographs, Topographic Maps, and Satellite Imagery. The Geographical Journal, 179, 248-263.

https://doi.org/10.1111/j.1475-4959.2012.00486.x

[21] Blomdin, R., Heyman, J., Stroeven, A.P., Hattestrand, C., Harbor, J.M., Gribenski, N., Jansson, K.N., Petrakov, D.A., Ivanov, M.N., Orkhonselenge, A., Rudoy, A.N. and Walther, M. (2016) Glacial Geomorphology of the Altai and Western Sayan Mountains, Central Asia. Journal of Maps, 12, 123-136. https://doi.org/10.1080/17445647.2014.992177

[22] Lehmkuhl, F. (2012) Holocene Glaciers in the Mongolian Altai: An Example from the Turgen-Kharkhiraa Mountains. Journal of Asian Earth Sciences, 52, 12-20. https://doi.org/10.1016/j.jseaes.2011.11.027

[23] Rudoy, A.N. and Rusanov, G.G. (2012) Last Glaciations of North-West Altai. Koksa River Catchment. NTL, Tomsk, 240.

[24] Owen, L.A. (2013) Late Quaternary in Highland Asia. In: Elias, S.A., Ed., Encyclopedia of Quaternary Science, Elsevier B. V., Amsterdam, 236-244. https://doi.org/10.1016/B978-0-444-53643-3.00119-9

[25] Tronov, M.V. (1949) Essays about Altai Glaciation. Geographgiz, Moscow, 376. (In Russian)

[26] Dolgushin, L.D. and Osipova, G.B. (1989) Glaciers. Mir, Moscow, 447. (In Russian)

[27] Gillespie, A.R., Burke, R.M., Komatsu, G. and Bayasgalan, A. (2008) Late Pleistocene Glaciers in Darhad Basin, Northern Mongolia. Quaternary Research, 69, 169-187. https://doi.org/10.1016/j.yqres.2008.01.001

[28] Krivonogov, S.K., Sheinkman, V.S. and Mistruykov, A.A. (2005) Stages in the Development of the Darhad Dammed Lake (Northern Mongolia) during the Late Pleistocene and Holocene. Quaternary International, 136, 83-94. https://doi.org/10.1016/j.quaint.2004.11.010

[29] Komatsu, G., Arzhannikov, S.G., Gillespie, A.R., Burke, R.M., Miyamoto, H. and 
Baker, V.R. (2009) Quaternary Paleolake Formation and Cataclysmic Flooding along the Upper Yenisei River. Geomorphology, 104, 143-164. https://doi.org/10.1016/j.geomorph.2008.08.009

[30] Selivanov, E.I. (1972) Neotectonics and Geomorphology of the Mongolian People's Republic. State Publishing House, Nedra, 293 p. (In Russian)

[31] Dashdeleg, N. (1990) Modern Glaciers of Mongolia. In: Academy of Sciences of Mongolia and Academy of Sciences of USSR, Eds., National Atlas of the Peoples Republic of Mongolia, Ulaanbaatar and Moscow, Moscow. (In Russian)

[32] Dashdeleg, N., Evilkhan, R. and Khishigsuren, P. (1983) Recent Glaciations of Mongolian Altai. Proceedings of IMH, No. 8, Institute of Meteorology and Hydrology, Ulaanbaatar, Mongolia, 121-126.

[33] Baast, P. (1998) Modern Glaciers and Hydrology of Mongolia. A Dissertation for Philosophical Doctor of Geography, Institute of Geoecology, Mongolian Academy of Sciences, Ulaanbaatar, 162 p. (In Russian)

[34] Enkhtaivan, D. (2006) Physical-Geographical Characteristics of the Altai Region. In: Vogtmann, H. and Dobrestov, N., Eds., Environmental Security and Sustainable Land Use: With Special Reference to Central Asia, Springer, Dordrecht, 349-351. https://doi.org/10.1007/1-4020-4493-3_24

[35] Yabouki, H. and Ohata, T. (2009) The Recent Glacier Changes in the Mongolian Altai Mountains. American Geophysical Union.

[36] Kadota, T. and Davaa, G. (2004) A Preliminary Study on Glaciers in Mongolia. In: Proceedings of the 2 nd International Workshop on Terrestrial Change in Mongolia, Institute of Meteorology and Hydrology, Ulaanbaatar, 100-102.

[37] Otgonbayar, D. (2012) Water-Glacier Resources of Closed Drainage Basins of Western Mongolia: Contemporary Assessment and Tendencies of Change: Extended Abstracts of Candidate Science. (Geography) Degree Dissertation, Izd-vo AtTGU, Barnaul, 24 p. (In Russian)

[38] Tronov, M.V. (1966) Glaciers and Climate. Gidrometeoizdat, Leningrad, 407. (In Russian)

[39] Institute of Meteorology and Hydrology (2013) A Report of Mongolian Weather and Climate. Institute of Meteorology and Hydrology, Ulaanbaatar, $113 \mathrm{p}$.

[40] Murzaev, E.M. (1952) The Description of Physical Geography of Mongolia. 2nd Edition, Moscow. (In Russian)

[41] Munkhtuya, Sh. (2004) A Dissertation for Philosophical Doctor of Geography on Technology and Methodology for Classifying Land Covers Using Satellite Data. Institute of Meteorology and Hydrology, Ulaanbaatar. (In Mongolian)

[42] Intergovernmental Panel on Climate Change (2007) Contribution of Working Groups I, II and III to the Fourth Assessment Report of the Intergovernmental Panel on Climate Change Core Writing Team. IPCC, Geneva, 104 p.

[43] World Glacier Monitoring Service (2008) Global Glacier Changes: Facts and Figures. In: Zemp, M., Roer, I., Kääb, A., Hoelzle, M., Paul, F. and Haeberli, W., Eds., World Glacier Monitoring Service, UNEP, Zurich, 88 p.

[44] Watanabe, M. (2010) Asia-Pacific Adaptation Network. Proceedings of Consultative Meeting on Integration of Climate Change Adaptation into Sustainable Development in Mongolia. Institute for Global Environmental Strategies (IGES), 3-5.

[45] Batima, P., Natsagdorj, L., Gomboluudev, P. and Erdenetsetseg, B. (2005) Observed Climate Change in Mongolia. AIACC Working Paper No. 12, 26 p.

[46] Sarantuya, C. and Natsagdorj, L. (2010) Climate Change in Mongolia. In: Proceed- 
ings of Consultative Meeting on Integration of Climate Change Adaptation into Sustainable Development in Mongolia, Institute for Global Environmental Strategies (IGES), 23-28.

[47] Institute for Global Environmental Strategies (2010) Proceedings of Consultative Meeting on Integration of Climate Change Adaptation into Sustainable Development in Mongolia. IGES Conference Report, Ulaanbaatar, 156 p.

[48] Altanbagana, M., Chuluun, T. and Ojima, D. (2010) Vulnerability Assessment of the Mongolian Rangeland Ecosystems. In: Proceedings of Consultative Meeting on Integration of Climate Change Adaptation into Sustainable Development in Mongolia, Institute for Global Environmental Strategies (IGES), 37-57.

[49] Dagvadorj, D. (2010) The Climate Change Policy and Measures in Mongolia. In: Proceedings of Consultative Meeting on Integration of Climate Change Adaptation into Sustainable Development in Mongolia, Institute for Global Environmental Strategies (IGES), 5-10.

[50] Karthe, D., Chalov, S. and Borchardt, D. (2015) Water Resources and Their Management in Central Asia in the Early Twenty First Century: Status, Challenges and Future Prospects. Environmental Earth Science, 73, 487-499.

https://doi.org/10.1007/s12665-014-3789-1

[51] Dukhovny, V.A., Sokolov, V.I. and Ziganshina, D.R. (2013) Integrated Water Resources Management in Central Asia, as a Way of Survival in Conditions of Water Scarcity. Quaternary International, 311, 181-188.

https://doi.org/10.1016/j.quaint.2013.07.003 